\title{
THE PHONOLOGY OF VOCALIC HEIGHT IN KIKURIA*
}

\author{
Chacha Nyaigotti Chacha \\ HELB, Nairobi \\ and \\ David Odden \\ The Ohio State University
}

\begin{abstract}
Vowel height harmony is common in Bantu languages, but the language Kikuria has a particularly rich system of vowel height alternations, which are described in this paper. Included in the height-related phonology of the language are three regressive height harmonies and one progressive harmony. Certain of these processes are triggered by glides and palatal consonants, while for other processes these consonants are transparent, and stem-initial vowels behave exceptionally for some, but not all, of these processes.
\end{abstract}

\section{Introduction}

Many Bantu languages have systems of vowel harmony whereby vowels in adjacent syllables assimilate in height, as discussed in Hyman [1988], Clements [1991], Parkinson [1996], inter alii. The language Kikuria, spoken in Kenya and Tanzania, has a rich system of vowel height alternations, and the purpose of this paper is to document the phonology of vowel height in this language. Phoneti-

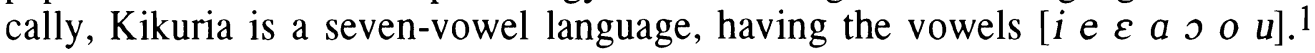

\footnotetext{
* Research for this paper was supported in part by NSF grant SBR-9421362.

1 Such vowel-height systems have been analysed in terms of the features [high], [low] and [ATR], as in Hyman [1988], or in terms of a single scalar feature [open] [Clements 1991] or [closed] [Parkinson 1996]. The primary argument for a scalar approach to vowel height is that it provides a unified account of height harmony affecting multiple vowels heights. While Kuria does have height harmony at different heights, strong arguments cannot be made that these harmonies reflect a single process.
} 
Four assimilatory processes exist in the language. The first process raises uppermid vowels $(e, o)$ to high vowels $(i, u)$ when they are followed by a high vowel, a glide, or a palatal consonant, as discussed in section 2 . The second process, investigated in section 3, raises a lower-mid vowel $(\varepsilon, \nu)$ to an upper-mid vowel when followed by a high vowel. Section 4 motivates a third process where a high vowel is lowered to an upper-mid vowel when followed by an upper-mid vowel. The fourth assimilation, the subject of section 5, lowers an upper-mid vowel to a lower-mid vowel when preceded by a lower-mid vowel. The status of palatal consonants and glides is taken up in section 6. Processes of vowel merger are documented in section 7, including glide formation and a process whereby the low vowel $a$ and the upper-mid vowels $e$ and $o$ become a single lower-mid vowel. Finally, the interaction of these effects is the subject of section 8 .

The goal of this paper is to describe the facts surrounding vowel height in Kikuria rather than to advance a particular theoretical viewpoint, so we have aimed to be neutral as to whether such generalizations should be captured in terms of rules, as is traditionally assumed, or in terms of a system of ranked constraints as assumed in Optimality Theory (see McCarthy \& Prince [1993] for an overview of Optimality Theory). References to "rules" and related concepts

$\begin{array}{ll}\text { (1) } \begin{array}{ll}\text { Prefix } \\ \text { omo- }\end{array} & \text { Class } \\ \text { aba- } & 1 \\ \text { omo- } & 3 \\ \text { eme- } & 4 \\ \text { iri- } & 5 \\ \text { ama- } & 6 \\ \text { eke- } & 7 \\ \text { ibi- } & 8 \\ \text { e(N)-3 } & 9 \\ \text { ichi( } N)- & 10 \\ \text { oro- } & 11 \\ \text { obo- } & 14 \\ \text { ogo- } & 20\end{array}$

2 Underlying $k$ in a prefix appears as $g$ when the following syllable contains a voiceless consonant (e.g., /eke-kébil $\rightarrow$ ege-kébi 'knife', /oko-táángál $\rightarrow$ ogo-táángá 'to begin') by a dissimilative process known as Dahl's Law.

3 The symbol $\mathrm{N}$ represents a nasal consonant which assimilates in place to a following stop, or deletes before a continuant or another nasal. The vowel of this prefix, as well as the second vowel of the cl. 10 prefix ichiN-, may surface as short (e-séésé 'cat') or as long (iin-gúrúbe 'pig'), owing to a process lengthening vowels before sequences of nasal plus consonant. The nasal is lacking in certain lexically specified nouns, e.g., i-tííni 'animal'. 
in this paper are thus purely heuristic. This paper draws insights from Cammenga [1994], who describes many of these same patterns. There are minor empirical differences between the version of the language described here and that described by Cammenga, and where these differences are important, we will point them out.

\section{Raising to high}

The first process in Kikuria phonology we shall discuss that is related to vowel height is a regressive harmony that raises any mid vowel to a high vowel when it is followed by another high vowel, glide, or palatal consonant. This raising operates within stems and prefixes. Evidence for the existence of this process comes from alternations in the form of the noun class prefix, as determined by the phonological properties of the following stem. The list in (1) provides the underlying forms of the noun class prefixes of Kikuria.

The shape of certain of these prefixes, namely those of classes $1,3,4,7,9$, 11,14 , and 20 , alternates so that a variant with a high vowel is employed before a stem whose first syllable contains a high vowel, as shown in (2).

\section{(2) Class 1}

\begin{tabular}{|c|c|c|}
\hline $\begin{array}{l}\text { omoó-nto } \\
\text { omo-sááchá }\end{array}$ & $\begin{array}{l}\text { 'person' } \\
\text { 'male' }\end{array}$ & $\begin{array}{l}\text { umu-ríísya } \\
\text { umu-múra }\end{array}$ \\
\hline
\end{tabular}

\section{Class 3}

$\begin{array}{lll}\text { omo-té } & \text { 'tree' umu-sí } & \text { 'sugar cane' } \\ \text { omo-góndo } & \text { 'plowed field' }\end{array}$

\section{Class 4}

$\begin{array}{lll}\text { eme-té } & \text { 'trees' imi-sí } & \text { 'sugar canes' } \\ \text { eme-góóndo } & \text { 'plowed fields' }\end{array}$

\section{Class 7}

$\begin{array}{llll}\text { ege-té } & \text { 'chair' } & \text { igi-túúmbe } & \text { 'stool' } \\ \text { ege-sáka } & \text { 'stream' } & \text { iki-múúñ́ } & \text { 'deer' } \\ \text { egeé-nto } & \text { 'thing' } & \text { iki-rúúngúuri } & \text { 'soft porridge' }\end{array}$

\section{Class 9}

$\begin{array}{ll}\text { e-séésé } & \text { 'dog' } \\ \text { e-ng'áámwí } & \text { 'cat' } \\ \text { e-ng'ómbe } & \text { 'cow' }\end{array}$

i-tíiñi

iin-gúrúbe 'animal'

'pig' 
Class 11

\begin{tabular}{llll}
$\begin{array}{l}\text { oro-té } \\
\text { oro-réme }\end{array}$ & 'stick' & uru-síri & 'rope' \\
oro-géna & 'tongue' & uru-gúta & 'wall' \\
oro-táre & 'grinding stone' & & \\
\hline
\end{tabular}

\section{Class 14}

$\begin{array}{llll}\text { obo-béébe } & \text { 'badness' } & \text { ubu-kíma } & \text { 'corncake' } \\ \text { obo-gááká } & \text { 'male adulthood' } & \begin{array}{l}\text { ubu-mítítu } \\ \text { ubu-kúningu }\end{array} & \begin{array}{l}\text { 'coldness' } \\ \text { 'female adulthood' }\end{array}\end{array}$

Class 20

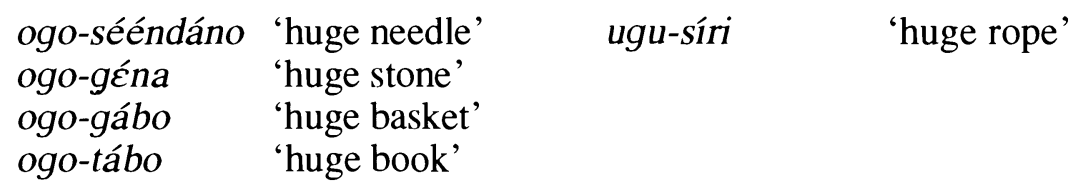

A low vowel in the prefixes for classes 2 and 6 does not change before a high vowel, as shown in (3), while the prefixes for classes 5,8 , and 10 contain a high vowel irrespective of the vowel of the following stem, as in (4).

(3) Class 2

$$
\begin{aligned}
& \text { aba-rísya } \\
& \text { aba-sááchá } \\
& \text { abaá-nto } \\
& \text { aba-múra }
\end{aligned}
$$

Class 6 ama-híindi

ama-síko

ama-té

ama-kéćndo

ama-tóóke

ama-tóro

(4) Class 5 iri-síko

iri-híindi

iri-té

iri-kéćndo

iri-tóóke

iri-tóro
'boys'
'males'
'people'
'young men'
'corn cobs'
'yards'
'big chairs'
'date fruits'
'bananas'
'buttocks' 


\begin{tabular}{|c|c|c|}
\hline Class 8 & $\begin{array}{l}\text { ibi-té } \\
\text { ibi-sáka } \\
\text { ibi-gááte } \\
\text { ibii-nto } \\
\text { ibi-góóndo } \\
\text { ibi-gúrúbe } \\
\text { ibi-túúmbe } \\
\text { ibi-rúúngúuri } \\
\text { ibi-múúné }\end{array}$ & $\begin{array}{l}\text { 'chairs' } \\
\text { 'streams' } \\
\text { 'small breads' } \\
\text { 'things' } \\
\text { 'small fields' } \\
\text { 'small pigs' } \\
\text { 'stools' } \\
\text { 'soft porridges' } \\
\text { 'deer (pl)' }\end{array}$ \\
\hline Class 10 & $\begin{array}{l}\text { ichiin-síri } \\
\text { ichi-tíñni } \\
\text { ichiin-té } \\
\text { ichiin-déme } \\
\text { ichi-séésé } \\
\text { ichiin-géna } \\
\text { ichiin-táre } \\
\text { ichi-ng'áámwi } \\
\text { ichi-ng ómmbe } \\
\text { ichiin-gúrúbe } \\
\text { ichiin-gúta }\end{array}$ & $\begin{array}{l}\text { 'ropes' } \\
\text { 'animal' } \\
\text { 'sticks' } \\
\text { 'tongues' } \\
\text { 'dog' } \\
\text { 'stones' } \\
\text { 'grinding stones' } \\
\text { 'cat' } \\
\text { 'cow' } \\
\text { 'pig' } \\
\text { 'walls' }\end{array}$ \\
\hline
\end{tabular}

Additional data which illustrate Raising to High involve the infinitive prefix oko-. This prefix has underlying upper-mid vowels, but has phonetic high vowels when the following syllable contains a high vowel, as in (5).
(5)

\begin{tabular}{|c|c|c|c|}
\hline oko-réma & 'to plow' & uku-gíingírá & 'to shave' \\
\hline oko-géćchá & 'to chop' & ugu-síiká & 'to close a door' \\
\hline ogo-táángá & 'to begin' & ugu-súraangá & 'to sing praise' \\
\hline $\begin{array}{l}\text { oko-róga } \\
\text { oko-hóórá }\end{array}$ & $\begin{array}{l}\text { 'to bewitch s.o.' } \\
\text { 'to thresh' }\end{array}$ & ugu-túúhá & 'to be blunt' \\
\hline
\end{tabular}

Raising to High also applies to an object prefix (as well as to the infinitive prefix preceding the object prefix). The underlying forms of the object prefixes are motivated in $(6 a, b)$, where they surface unmodified because the following vowel is a, a vowel which triggers no vowel harmony. The object prefixes for classes 8 and 10 have underlying high vowels, so these prefixes themselves cause raising of preceding upper-mid vowels $(6 c)$.
(6) a. ogo-kó-báră 'to count you (sg)'
oko-mó-báră 'to count him'
ogo-tó-báră 'to count us'


(6) b. oko-gó-báră 'to count it (cl 3)'

oko-gé-báră 'to count it (cl 4)'

oko-ré-báră 'to count it (cl 5)'

oko-ró-báră 'to count it (cl 11)'

oko-bó-báră 'to count it (cl 14)'

c. uku-bí-báră 'to count it (cl 8)'

ugu-chí-báră 'to count it (cl 10)'

When placed before a stem whose first vowel is high, the vowels of object prefixes (and the preceding infinitive prefix) become high, as in (7). The raising process applies to multiple object prefixes, as in (8), but if the vowel a appears in one of the object prefixes, as in (9), raising does not extend to or before that prefix.

(7) uku-gú-súraánga

uku-mú-súraánga

ugu-tú-súraánga

uku-gú-súraánga

uku-gí-súraánga

uku-rí-súraánga

uku-bí-súraánga

ugu-chí-súraánga

uku-rú-súraánga

uku-bú-súraánga

(8) oko-mó-gó-gesćra

uku-mú-mú-giíngíra

uku-mú-gú-siíkya

uku-mú-gú-siíndya

uku-mú-mú-giíngíra

(9) oko-bá-súraánga

oko-mó-bá-suráángéra

oko-bá-mú-suráángéra 'to praise you (sg)'

'to praise him'

'to praise us'

'to praise it (3)'

'to praise it (4)'

'to praise it (5)'

'to praise it (8)'

'to praise it (10)'

'to praise it (11)'

'to praise it (14)'

'to harvest it (3) for him'

'to shave it (3) for him'

'to make him close it (3)'

'to make him win it (3)'

'to shave him in there'

'to praise them'

'to praise them for him'

'to praise him for them'

Vowel raising also affects the subject prefix, as illustrated in (10) and (11) with data from the perfective and subjunctive forms of verbs. The underlying form of the subject prefixes can be seen in (10) when the following vowel is non-high. Raising to High applies to the subject prefix before a high vowel, as in (11). 
(10) PERFECTIVE

\begin{tabular}{|c|c|}
\hline 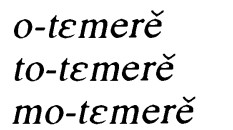 & $\begin{array}{l}\text { 'you (sg.) hit' } \\
\text { 'we hit' } \\
\text { 'you (pl.) hit' }\end{array}$ \\
\hline $\begin{array}{l}\text { o-reenderé } \\
\text { to-reenderé } \\
\text { mo-reenderé }\end{array}$ & $\begin{array}{l}\text { 'you (sg.) guarded' } \\
\text { ‘we guarded' } \\
\text { 'you (pl.) guarded' }\end{array}$ \\
\hline
\end{tabular}

SUBJUNCTIVE

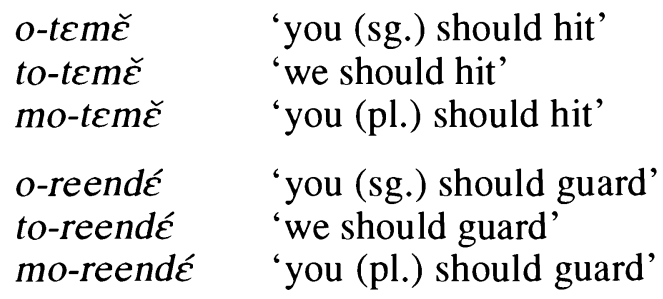

(11) PERFECTIVE

$\begin{array}{ll}\text { u-siikeré } & \text { 'you (sg.) closed' } \\ \text { tu-siikeré } & \text { 'we closed' } \\ \text { mu-siikeré } & \text { 'you (pl.) closed' } \\ u \text {-sukerě } & \text { 'you (sg.) plaited' } \\ \text { tu-sukerě } & \text { 'we plaited' } \\ \text { mu-sukerě } & \text { 'you (pl.) plaited' }\end{array}$

SUBJUNCTIVE

$\begin{array}{ll}u \text {-siiké } & \text { 'you (sg.) should close' } \\ \text { tu-siiké } & \text { 'we should close' } \\ m u \text {-siiké } & \text { 'you (pl.) should close' } \\ \text { u-huuté } & \text { 'you (sg.) should blow' } \\ \text { tu-huuté } & \text { 'we should blow' } \\ m u-h u u t \varepsilon ́ & \text { 'you (pl.) should blow' }\end{array}$

Up to this point, all examples of Raising to High have involved assimilation initiated by a stem-initial high vowel. Such raising is also found within the stem. An agentive nominalisation is formed by affixing the vowel $-i$ to a stem, the resulting noun being in classes 1-2. When the stem contains a mid vowel, that 
vowel is raised to become a high vowel. This derived high stem vowel causes raising of the preceding prefix vowel, as in (12). ${ }^{4}$

$\begin{array}{llll}\text { (12) } & \text { 'farmerimi } & <\text { okoréma } & \text { 'to cultivate' } \\ \text { umutígíti } & \text { 'one who is late' } & <\text { ogotégétă } & \text { 'to be late' } \\ \text { umuhíítúki } & \text { 'rememberer' } & <\text { okohéétóká } & \text { 'to remember' } \\ \text { umurúmi } & \text { 'biter' } & <\text { okoróma } & \text { 'to bite' } \\ \text { umusúúki } & \text { 'respecter' } & <\text { ogosóóká } & \text { 'to respect' } \\ \text { umuhúúri } & \text { 'thresher' } & <\text { okohóórá } & \text { 'to thresh' } \\ \text { omotáchúri } & \text { 'one who unties' } & <\text { ogotáchóră 'to tear' }\end{array}$

Upper-mid vowels within the verb stem will raise to high vowels when the causative suffix is added. We assume that the causative suffix is underlying $/ \mathrm{i} /$, though it surfaces as [y] before a vowel due to a process of Glide Formation. Data from the imperative are given in (13) to illustrate Raising to High conditioned by the causative.

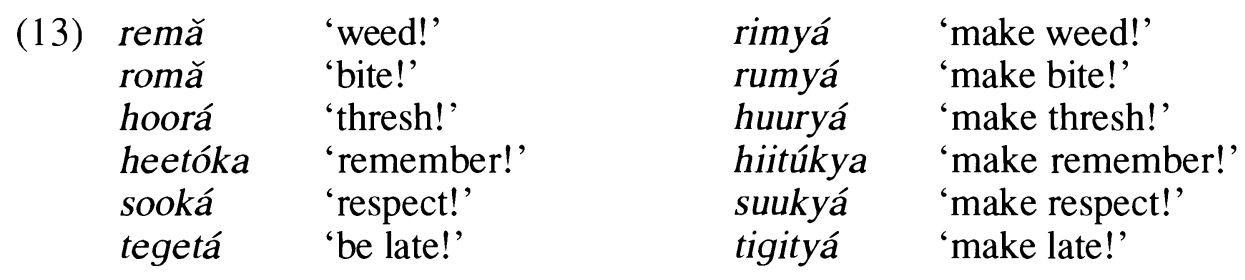

Evidence from tonal alternations-discussed in Odden [1987]—-supports the claim that the causative suffix is underlyingly - $i$-. In the imperative, a $\mathrm{H}$ tone is assigned to the third stem vowel (mora), as in heetóka, tegetá, or hoorá, but if the stem does not contain three vowels, as in remă, the $\mathrm{H}$ tone is mapped to the stem as a rising tone. On the surface, the form rimyá with a level $\mathrm{H}$ would appear anomalous since the stem has only two vowels, but the final vowel has a level $\mathrm{H}$ and not a rising tone. This anomaly is explained by the assumption that [rimyá] is underlying/rem-i-a/, in which case this form follows the general

\footnotetext{
4 Implicit in our analysis is the prediction that upper-mid vowels do not appear within a stem before high vowels. Such a prediction appears to be counterexamplified by words such as umweéri 'moon'. As we will show in section 3, the lower-mid vowel $\varepsilon$ raises to $e$ before a high vowel. We would thus assume that the underlying form of this noun stem is $\varepsilon r i$, which is indeed its form in many Bantu languages. Analogously, we assume that omorógi 'witch' derives from lomo-rogi/. In the latter case, direct confirmation of the hypothesis comes from the fact that this noun derives from the verb stem -rog-, cf. okoróga 'to bewitch'. It is the lack of any means whereby the final vowel $i$ of the noun umweéri can be replaced with a nonhigh vowel that prevents us from directly demonstrating the hypothesized underlying quality of the stem initial vowel in this case.
} 
pattern for verbs having three vowels, i.e., a level $\mathrm{H}$ appears on the final vowel. The high vowel desyllabifies giving the surface form [rimyá].

Raising to High triggered by the causative suffix will iteratively cause the stem vowels and preceding prefix vowels to raise to high vowels, as in (14).

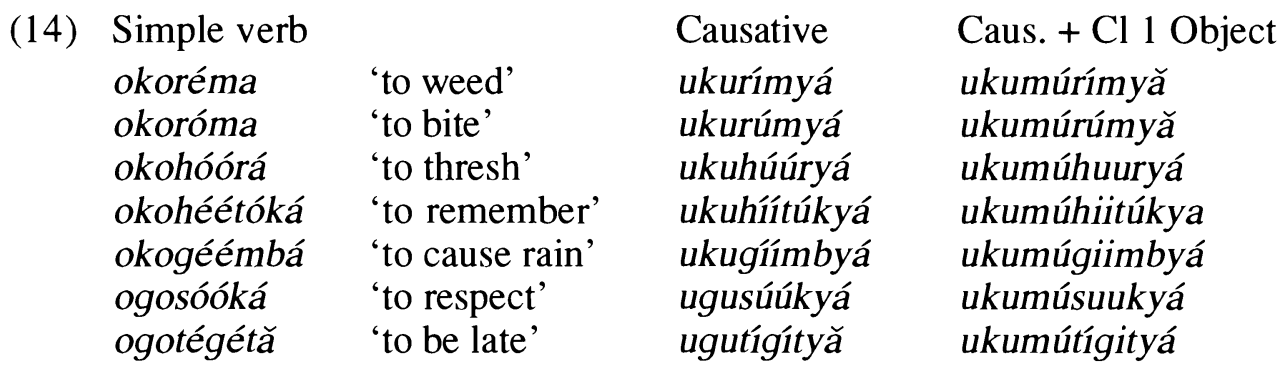

In one phonological context, mid vowels do not raise to high when followed by a high vowel, namely when the mid vowel is in absolute stem initial position. We will also show in section 4 that the process lowering high vowels to uppermid vowels before upper-mid vowels also does not apply to a vowel in initial position within the stem; however, section 3 documents a process raising lowermid vowels to upper-mid, which does apply in stem initial position. Note furthermore that the restriction against raising to high does not extend to wordinitial position, as in [ukurímyá] 'to cause to cultivate' from /oko-rem-i-a/. Downing [1998] discusses a number of cases from other Bantu languages where stem-initial vowels have unusual phonological properties.

\begin{tabular}{|c|c|c|c|c|}
\hline & $\begin{array}{l}\text { egă } \\
u k w \text {-eéga }\end{array}$ & $\begin{array}{l}\text { 'learn!' } \\
\text { 'to learn' }\end{array}$ & $\begin{array}{l}\text { egyá } \\
\text { ukw-eégya }\end{array}$ & $\begin{array}{l}\text { 'teach!' } \\
\text { 'to teach' }\end{array}$ \\
\hline & $\begin{array}{l}\text { ebă } \\
u k w \text {-eéba }\end{array}$ & $\begin{array}{l}\text { 'forget!' } \\
\text { 'to forget' }\end{array}$ & $\begin{array}{l}\text { ebyá } \\
\text { ukw-eébya }\end{array}$ & $\begin{array}{l}\text { 'cause to forget!' } \\
\text { 'to cause to forget' }\end{array}$ \\
\hline b. & $\begin{array}{l}\text { oongoká } \\
\text { oko-óngókă }\end{array}$ & $\begin{array}{l}\text { 'be clear!' } \\
\text { 'to be clear' }\end{array}$ & $\begin{array}{l}\text { oongokyá } \\
\text { oko-óngókyă }\end{array}$ & $\begin{array}{l}\text { 'clarify!'6 } \\
\text { a'to clarify' }\end{array}$ \\
\hline & $\begin{array}{l}\text { ogă } \\
\text { oko-óga }\end{array}$ & $\begin{array}{l}\text { 'be sharp!' } \\
\text { 'to sharpen' }\end{array}$ & $\begin{array}{l}\text { ogyá } \\
\text { oko-ógyá }\end{array}$ & $\begin{array}{l}\text { 'sharpen!' } \\
\text { 'to sharpen' }\end{array}$ \\
\hline & $\begin{array}{l}\text { oroóra } \\
\text { omo-óroorí }\end{array}$ & $\begin{array}{l}\text { 'float!' } \\
\text { 'floater' }\end{array}$ & oroórya & 'cause to float!' \\
\hline
\end{tabular}

\footnotetext{
5 Raising of the prefix vowel to [u] is conditioned by the derived glide [w], and will be discussed in section 6 .

6 The underlying form of this stem has an initial short vowel, and thus abstracting away form the pre-NC lengthening process, the third mora appears in the final syllable.
} 
In the case of oroórya, one might expect a form such as *oruúrya, where the initial vowel is exempt from raising, but medial oo is not. However, there is a process of progressive vowel lowering, discussed in section 5 , which prevents $u$ after $\boldsymbol{o}$.

To summarize, whenever an underlying upper-mid vowel is followed by a high vowel, the mid vowel raises to become a high vowel. In addition, in a sequence of consecutive upper-mid vowels, each vowel is raised to become a high vowel. The presence of an intervening low vowel blocks this process. As we will see in section 6, Raising to High is also triggered by certain nonsyllabic segments, specifically glides and palatal consonants.

\section{Raising to mid}

A similar process raises the lower-mid vowels $\varepsilon$ and $\lrcorner$ to $e$ and $o$ when they are followed by a high vowel. This can be seen in the alternations between the basic form of the verb, which shows the underlying lower-mid vowel, and an uppermid vowel in the causative, which is conditioned by the (underlying) vowel /i/, as in (16).

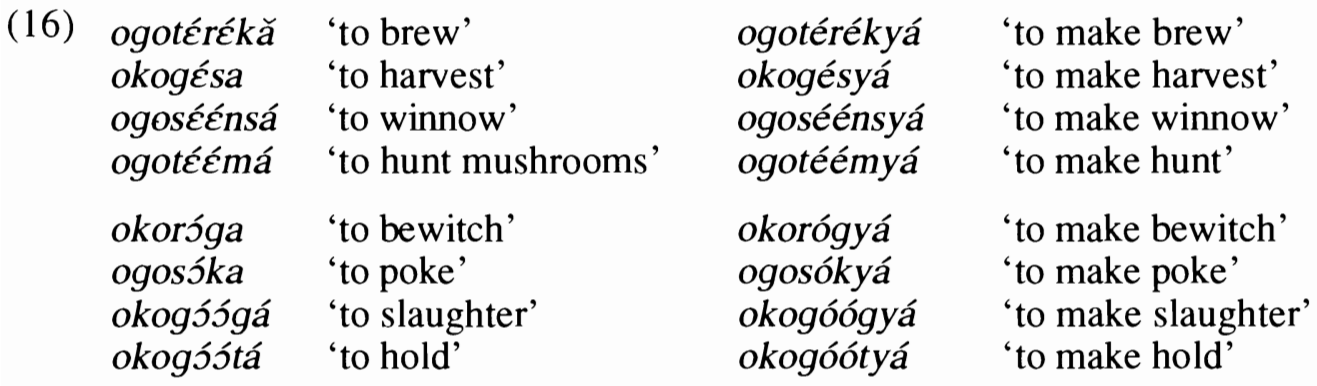

Further evidence for Raising to Mid is seen in the form of agent nominalizations of verbs with an underlying lower-mid vowel (17). Abstract nominalizations with the final vowel $-u$ also provide evidence for this process, as in (18).
(17) omogési
'harvester'
omotéréki
'brewer'
omotéémi
'mushroom hunter'
omorógi
'witch'
omogóógi
'butcher'
omogóóti
'holder' 

(18) obo-téréru
'slipperiness'
< ogo-téréră
'to be slippery'
obo-téreeréku
'smoothness'
$<$ ogo-térecréka
'to be smooth'
obo-tééndééru 'smoothness'
< ogo-tééndééra
'to be smooth'

Unlike the processes of raising upper-mid vowels before high vowels and lowering high vowels before upper-mid vowels, this process does affect a lower-mid vowel in absolute initial position in the stem, as shown by the examples in (19).
(19) eyyá
'cause to sweep!'
$\varepsilon y a ̆$
$u k w-\varepsilon \varepsilon ́ y a$
'sweep!'
ukw-eéyya
'to cause to sweep'
umw-eéyi
'sweeper'
eremyá 'make swim!'
Eremá
'swim!'
ukw-eégékyă
'to prop up'
ukw-عÉgékă
oyokyá
'make greedy!'
syoká
ok-oóyókyă 'to make greedy'
ok-oว́yókă
'to sweep'
orokyá
'verify!'
oroká
'to be propped up'
'be greedy!'
'to be greedy'
'come out!'7

The only examples of Raising to Mid are drawn from within the stem domain. In general, prefixes do not contain lower-mid vowels. However, the negative infinitive prefix toko does, and as the data in (20) show, that prefix does not undergo Raising to Mid.

ogo-tókó-réma

ogo-tógú-súraangá

ogo-tógú-gíintuúngúnúuchirya 'to not cultivate'

'to not praise'

'to not balance it for me'

The significance of these data is the following. Given the functional similarity of the Raising to Mid and Raising to High, it is natural to consider that these processes might be manifestations of a single generalization. ${ }^{8}$ We know of

7 This verb relates to an initiation rite whereby the initiate emerges from hiding and demonstrates her maturity, passing from stage obosaamba to ubwiiseke.

8 Cammenga 1994 assumes that the rules are the same, framing an analysis within the scalar height approach of Clements 1991. One fact might be taken to indicate that the two raising processes are distinct, namely the fact (discussed in section 6) that glides and palatal consonants trigger Raising to High but do not trigger raising to Mid. However, this may follow from the representation of height features on nonsyllabics in the language, rather than arising from a stipulated difference in the triggers of the two rules. Since it is not clear exactly what the theoretical basis is for the ability of nonsyllabic segments to trigger Raising to High, we do not take this difference in behavior as an unambiguous indication that the two raising processes must be governed by distinct rules. 
no incontrovertible evidence showing that the processes are formally distinct, so, for example, in an analysis employing ordered rules, no other rule can be shown to be ordered between these two rules. On the other hand, we know of no evidence that these processes must necessarily be covered by a single generalization. If the domains of the processes were to differ, that would preclude their being expressed by a single rule. The evidence in (20) suggests that the processes do indeed have different domains, Raising to Mid applying only within the stem domain and Raising to Hi applying throughout the word. On the other hand, since there is only one prefixal morpheme, the negative infinitive, which resists Raising to Mid, this morpheme might simply be an exception. Lacking conclusive evidence regarding the unity of these processes, we leave this issue open.

One final point must be made regarding the operation of Raising to Mid. If a stem contains a sequence of lower-mid vowels followed by a high vowel, each of the lower-mid vowels will be raised, as shown by omotéréki 'brewer', from ogotérékă 'to brew'. This could be explained in one of two ways. One possibility is that this harmony simultaneously affects the maximal sequence of lower-mid vowels, raising the entire sequence in a single step. Another possibility is that harmony iterates throughout the string, raising the right-most vowel in the sequence, which then creates a new conditioning context for harmony; thus, /omoter $\varepsilon \mathrm{ki} /$ becomes omotereki and then omotereki. Under this scenario, the lower-mid vowel in the syllable $t \varepsilon$ would raise not because of the vowel $i$ but because of the derived vowel $e$ in the following syllable. It would therefore be necessary to expand the conditioning context for Raising to Mid to include both high vowels and upper-mid vowels.

At this point, it is not possible to conclusively determine whether upper-mid vowels trigger Raising to Mid. Various stem suffixes, including the applied el and the neuter ek, contain upper-mid vowels. However, when these suffixes are added to a stem ending with a lower-mid vowel, they themselves are lowered to lower-mid by a progressive harmony discussed in section 5. Thus, /oko-tereker-a/ surfaces as ogotérékerá 'to brew for'. One suffix, the perfective affix -ere, contains upper-mid vowels and does not undergo progressive lowering, as seen in otemeré 'you (sg.) hit'. One should note that this suffix also does not condition application of Raising to Mid to the vowel $\varepsilon$. While this suffix might simply be marked as an exception to Raising to Mid, its failure to condition raising casts some doubt on the claim that upper-mid vowels trigger this raising process. Lacking convincing empirical evidence as to whether upper-mid vowels directly trigger Raising to Mid, we leave open for the moment the question of the mode of application for this process. ${ }^{9}$ In section 7 , however, we show that

${ }^{9}$ Cammenga 1994 notes the existence of another raising process whereby lower-mid vowels are raised to upper-mid when followed by an upper-mid vowel, whereby /m-ba-som-ere/ appears as mbasomeré 'they read'. As observed in section 5, an upper-mid vowel followed by a lower- 
although merger of the vowel sequence /oa/generally yields 00 when that vowel is followed by the non-harmonizing final vowel of the stem -áme 'rich', the expected lower-mid vowel surfaces as upper-mid, viz. /omo-áme/ $\rightarrow$ [omoóme] 'rich (cl. 1)'. This supports the view that both high vowels and upper-mid vowels trigger raising of lower-mid vowels.

\section{Regressive lowering}

The third height-related process applies only within the stem, and lowers a high vowel to an upper-mid vowel when the high vowel is followed by a mid vowel. The applied suffix -er-, the statives -ek-and -ok-, and the reversive -or-all trigger this vowel lowering process. The following data, where the final stem vowel is non-high, establish that these suffixes have underlying upper-mid vowels.
a. oko-réénd-ér-á10
'to guard for'
oko-géémb-ér-á
'to cause rain'
oko-báámb-ér-á
'to fit a drum head for'
ogo-táángát-ér-a
'to lead for'
ugu-súraang-ér-a
'to praise for'
oko-hóór-ér-á
'to thresh for'
b. ogo-sár-ék-ă
ogo-sáámb-ék-á
uku-ñáhaar-ék-a
'to be destroyed'
'to be roasted'
'to be hurt'
c. ogo-táánd-ók-á
ogo-táánd-ór-á

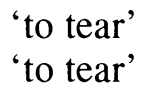

The data in (22) show that a stem with a high vowel is lowered when it is followed by a suffix with an upper-mid vowel. This lowering process does not operate between the stem and a prefix vowel, as the nominal data in (23) demonstrate. Analogous failure of lowering to affect a prefix is illustrated by the invariance of object prefixes containing high vowels in (24).

mid vowel generally becomes a lower-mid vowel. However, the perfective suffix does not undergo that lowering harmony. In the dialect we describe, that suffix does not trigger raising of lower-mid vowels, hence the surface form is mbasomeré.

10 In normal speech, a non-low vowel is severely reduced or perhaps deleted when within the stem it appears in the context $\mathrm{VC} \_\mathrm{rV}$, where $\mathrm{C}$ is $r, n t$ or $n d$. Thus ogorééndérá appears phonetically as [ogorééndra]. Rounding of the preceding consonant is found when the vowel is round. We have no evidence indicating whether this process is a categorial phonological process or a phonetic one. 
(22)

ogoséékérá
ogosééndérá
okorééngérá
okorógéră
ogosókéră

okobónékă

okorébóră
okohéétóká
okorééngórá
ogotókóră

okohótókă 'to close for'

'to win for'

'to fold for'

'to cook for'

'to plait for'

'to be broken'

'to unblock'

'to remember'

'to unfold'

'to dig up'

'to disappear through rubbing'

\section{(23)}

$\begin{array}{cll}\text { Class } 5 & \begin{array}{l}\text { irité } \\ \text { iritóro }\end{array} & \text { 'aug. chair' } \\ & \text { 'buttock' }\end{array}$

$\begin{array}{lll}\text { Class } 8 & \begin{array}{l}\text { ibigóóndo } \\ \text { ibité } \\ \text { ibiínto }\end{array} & \begin{array}{l}\text { 'small fields' } \\ \text { 'chairs' } \\ \text { 'things' }\end{array}\end{array}$

$\begin{array}{lll}\text { Class } 10 & \begin{array}{l}\text { ichiséésé } \\ \text { ichiindéme } \\ \text { ichiinté }\end{array} & \begin{array}{l}\text { 'dog' } \\ \text { 'tongues' } \\ \text { 'sticks' }\end{array}\end{array}$

(24) uku-bí-rémă 'to cultivate them (8)' ugu-chí-rémă 'to cultivate them (10)'

The perfective suffix -ere does not trigger regressive lowering (25), nor do so-called final vowel morphemes (26).

(25) u-sukerě
tu-sukerě (26) 'you (sg.) plaited'

'we plaited'

'to be deaf'

'to deny' mu-sukerě 'you (pl.) plaited'

$$
\begin{array}{ll}
\text { < ugusíiká } & \text { 'to close' } \\
<\text { ugusíindá } & \text { 'to win' } \\
<\text { ukuriingá } & \text { 'to fold' } \\
<\text { ukurúga } & \text { 'to cook' } \\
<\text { ugusúka } & \text { 'to plait' }
\end{array}
$$

< ukubúna 'to break'

$<$ ukuríba 'to block'

$<$ ukuhíitá 'to remember'

< ukuríingá 'to fold'

< ugutúka 'to dig'

$<$ ukuhúta 'to rub off'

Regressive lowering is also blocked in one further context; when a verb root begins with a high vowel (27), there is no lowering of that initial vowel. This is analogous to the failure of Raising to High to apply in stem initial position. 


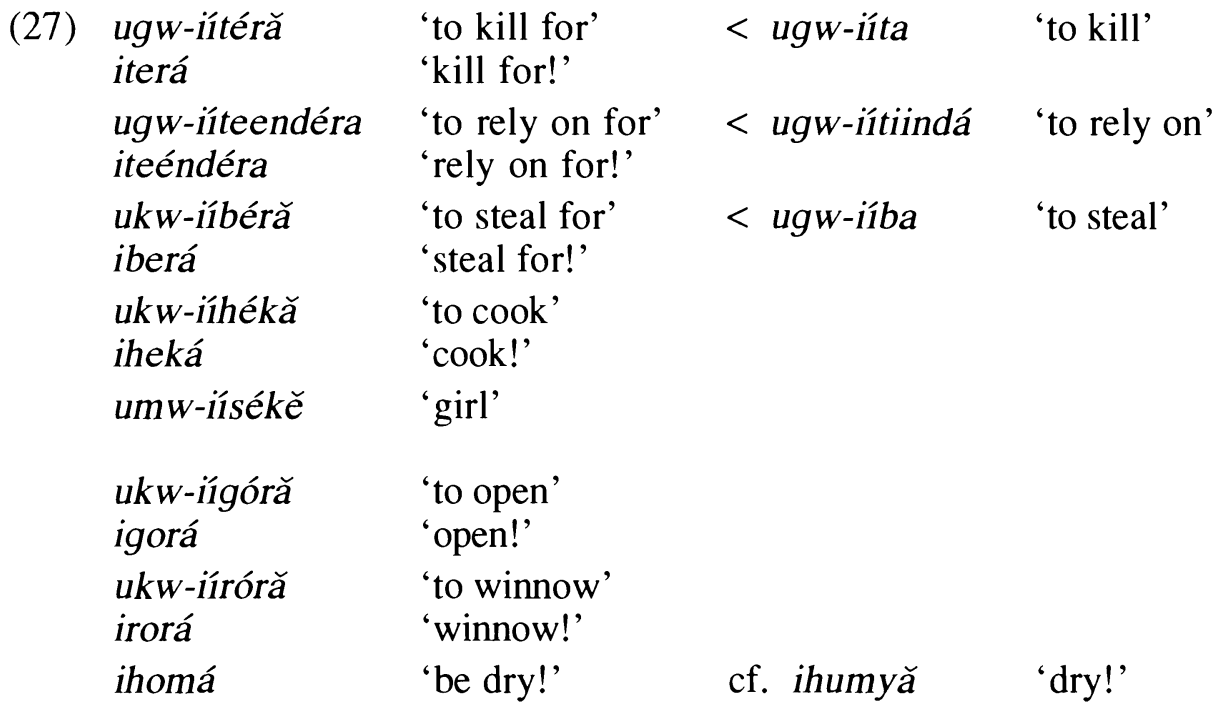

We are aware of no verb roots beginning with the vowel $u$, so it is possible that this particular type of failure of Regressive Lowering is restricted to the vowel $i$.

\section{Progressive lowering}

The fourth harmony process is a progressive harmony turning upper-mid vowels - for example, that of the applied suffix -er-into lower-mid vowels after a lower-mid vowel, as in the data in (28), which include the applied forms of stems ending in a lower-mid vowel.

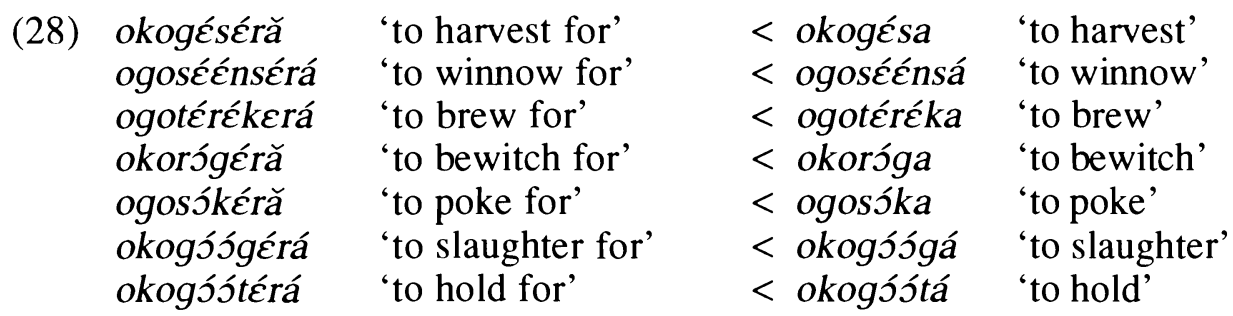

Given that lower-mid vowels do not generally appear in prefixes, the number of contexts where progressive lowering might apply is necessarily restricted. As previously noted, the negative infinitive prefix -toko- contains lower-mid vowels, and as the data in (29) show, the vowel $\supset$ does not trigger lowering of the following vowel (which is always the vowel $o$ of that same prefix). This might indicate a domain restriction such that only stem vowels 
trigger lowering; or, this one prefix might be an exception to Progressive Lowering.

(29) ogotókóréma
ogotókóróma

One suffix, the perfective -ere, is an exception to Progressive Lowering. As the examples in (30) show, the upper-mid vowels of the perfective do not lower.
(30) osęnseré
tosęnseré
'you (sg.) winnowed'
mosénseré
'we winnowed'
orogerě
torogerě
'you (pl.) winnowed'
'you (sg.) bewitched'
morogerě
'we bewitched'
'you (pl.) bewitched'

There is some evidence that Progressive Lowering will lower a high vowel after an upper-mid vowel. Although /o...i/ becomes [u...i] by Raising to High, recall also that Raising to High cannot apply to a stem-initial vowel. In cases such as the causative form oroórya 'cause to float!' and the agent nominalization omoóroori 'floater', Raising to High would be expected to yield *oruúrya and *omoóruurí. However, assuming that Progressive Lowering applies here as well, and is triggered by an upper-mid vowel, the correct surface forms will result.

Additional contexts where Progressive Lowering applies will be discussed in section 8 , in the discussion of the interaction between Progressive Lowering and vowel merger.

\section{Nonsyllabic Triggers}

Certain consonants enter into the picture regarding height alternation. As the following data demonstrate, Raising to High is triggered by the palatal consonants $c h$ and $\tilde{n}$, as shown by the fact that the prefix vowel preceding these consonants is high even if the vowel of the stem is non-high. Data involving nominal stems are seen in (31), verbal infinitives in (32).
(31) Class 1
umuchóóri
'drawer'
Class 3
umucháre
'rice'
Class 4
imicháre
'rices'
imichóka
imichóóngwa
imichárra
'huge snakes'
'huge oranges'
'huge cattle egrets' 

Class 7
ikiñúñi
'bird'
igichóka
'snake'
ikiñáánki
'grass'
igicháiné
'civet'
Class 9
iñáámwí
'cat'
Class 14 ubuñáánki
'grass'
Class 20 uguchóka
'huge snake'
uguchóóngwa
'huge orange'
uguchárra
'huge cattle egret'
uguchááncháárya
uguchóórá
'to boil (intransitive)'
'to spread open'
ukuñéćrá
'to draw'
ukuñáámúúra
ukuñáhaará
ukuñóórá
'to eat for'
'to dismember animal and drag off'
'to injure'
'to get'

(32) uguchémókă

A third source of palatal consonants which trigger this raising is the first person singular object prefix $\tilde{n}$, which appears before a vowel (33). Notice that when this object prefix is immediately followed by a consonant (34), it assimilates in place of articulation to that consonant or else deletes before a nasal or a continuant, and in either case does not trigger Raising to High (except in those cases in which the following consonant is a palatal or the following vowel is a high vowel: under either condition Raising proceeds as expected).

(33)
ukuú-ñ-ébă
ukuú-ñ-áherá
ukuú-ñ-aandékéra1 1
ukuú-ñ-óbohyá
ugu-kúú-ñ-óbóhírya

'to forget me'

'to pick vegetables for me'

'to write for me'

'to scare me'

'to make me scare for you'

11 The second vowel of the infinitive prefix is lengthened because of the following $1 \mathrm{sg}$. object prefix. This lengthening is somewhat surprising, since lengthening in Bantu is usually only found before preconsonantal nasals. We assume that the $1 \mathrm{sg}$. object prefix and the $1 \mathrm{sg}$. subject prefix are underlyingly moraic, and that this lengthening is just a standard case of compensatory lengthening. 


$\begin{array}{ll}\text { (34) } \begin{array}{l}\text { okoómaahá } \\ \text { okoóheetóka }\end{array} & \text { 'to see me' } \\ \text { okoómbáră } & \text { 'to remember me' } \\ \text { okoóndógă } & \text { 'to count me' } \\ \text { ukuúmbuuryá } & \text { 'to bewitch me' } \\ \text { uguúntuuryá } & \text { 'to ask me' } \\ \text { uguúnchoŕra } & \text { 'to help me' } \\ \text { ukuúññooryá } & \text { 'to draw for me'12 }\end{array}$

Glides also trigger Raising to High. In some instances, the triggering glide transparently derives from an underlying high vowel (35), in which case it is just as plausible that an underlying high vowel is the trigger of raising as it is that a derived glide is the trigger. In other cases (36), an underlying mid vowel becomes a glide, but the following vowel is high, so it is impossible to determine whether raising is triggered by the glide or the high vowel. In still other instances (37), the trigger of raising in the prefix is underlyingly a mid vowel which becomes a glide because of the general prohibition against vowel-vowel sequences in the language, and when followed by a non-high vowel, such examples provide unambiguous evidence that glides trigger Raising to High.

\begin{tabular}{|c|c|c|c|}
\hline (35) & $\begin{array}{l}\text { uku-by-áándék } \\
\text { uku-rúmyá }\end{array}$ & $\begin{array}{l}\text { 'to } \mathrm{v} \\
\text { 'to c }\end{array}$ & $\begin{array}{l}\text { em (8)' } \\
\text { bite' }\end{array}$ \\
\hline (36) & $\begin{array}{l}\text { umwiíséke } \\
\text { ugwiíta } \\
\text { ugwiísaabyá } \\
\text { ukwiíba }\end{array}$ & $\begin{array}{l}\text { /omo-íséke/ } \\
\text { /oko-íta/ } \\
\text { /oko-ísaabiá/ } \\
\text { /oko-íba/ }\end{array}$ & $\begin{array}{l}\text { 'girl' } \\
\text { 'to kill' } \\
\text { 'to wash oneself' } \\
\text { 'to steal' }\end{array}$ \\
\hline (37) & $\begin{array}{l}\text { imyeéri } \\
\text { imyoóro } \\
\text { imyoócho } \\
\text { imyoóño } \\
\text { ikyoóño } \\
\text { umweébi } \\
\text { umweéri } \\
\text { ukweéba } \\
\text { ugutwéébá } \\
\text { umwoócho }\end{array}$ & 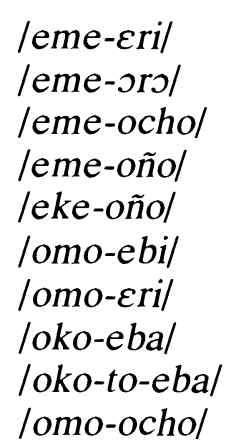 & $\begin{array}{l}\text { 'months' } \\
\text { 'rivers' } \\
\text { 'sorts' } \\
\text { 'salts' } \\
\text { 'salt (dim)' } \\
\text { 'forgetter' } \\
\text { 'month' } \\
\text { 'to forget' } \\
\text { 'to forget us' } \\
\text { 'sort' }\end{array}$ \\
\hline
\end{tabular}

\footnotetext{
12 This word would derive from /oko-ń-chooréra/, with $\varepsilon$ being deleted between $r$ 's; its tone is transfered to the preceding consonant which closes the syllable. The underlying long vowel appears to be phonetically shortened because the following $[r]$ functions as a coda consonantthough since there are otherwise no coda consonants in the language, it is impossible to test this hypothesis independently.
} 
In yet other instances (38), the glide is wholely contained within a root and there is no alternation between vowel and glide which might directly motivate the claim that the triggering segment is anything other than a glide.

$\begin{array}{ll}\text { (38) } \begin{array}{ll}\text { ukuyá } \\ \text { umuyéćmbe }\end{array} & \text { 'to go' } \\ \text { ubusyó } & \text { 'forango tree' } \\ \text { ugusyóómá } & \text { 'to peer' } \\ \text { ukubyóórá } & \text { 'to dip sth. out of water' } \\ \begin{array}{l}\text { ugukwá } \\ \text { ukuñwá }\end{array} & \text { 'to die' } \\ \text { ugutwá } & \text { 'to drink' } \\ \text { ugutwáángá } & \text { 'to pick fruit' } \\ \text { ukugwéémá } & \text { 'to hund' } \\ \text { ugutwééná } & \text { 'to divide' }\end{array}$

Not every surface glide triggers Raising to High. The glide $w$ of the passive suffix in (39) never raises upper-mid vowels to high vowels (nor does it cause raising of lower-mid vowels to upper-mid vowels, though, as we will demonstrate later in this section, one would not expect raising in such a case).13 In some nouns as well (40), the glide $w$ does not trigger raising of a preceding prefix vowel.

$\begin{array}{ll}\begin{array}{l}\text { ukwiíhékwă } \\ \text { okorémwa }\end{array} & \begin{array}{c}\text { 'to be cooked' } \\ \text { okohómérwă }\end{array} \\ \begin{array}{l}\text { 'to be weeded } \\ \text { okogééchwá }\end{array} & \text { 'to be poured for' } \\ \text { okogóótwá } & \text { 'to be touched' } \\ \text { okogóógwá } & \text { 'to be slaughtered' } \\ \text { okorómwa } & \text { 'to be bitten' } \\ \text { okobáárórwá } & \text { 'to be split' }\end{array}$

(40)

$\begin{array}{ll}\text { ekegwé } & \text { 'yam' } \\ \text { ekebwé } & \text { 'fox' } \\ \text { ekewéére } & \text { 'gnu' } \\ \text { ekwáási } & \text { 'fly whisk }\end{array}$

eengwé
eeng'wééna
ogohwá

'leopard'

'crocodile'

'huge thorn'

13 We would not analyse the passive suffix as underlyingly being a vowel on the grounds that it does not have the tonal properties of underlying vowels. Thus there is a tonal contrast between okobára 'to count' and okobárwa 'to be counted' with a HL tone pattern, versus okobáryá 'to cause to count' with a $\mathrm{HH}$ tone pattern. As we have noted previously in section 2, the causative suffix behaves as though it is a tone-bearing unit; the passive, in contrast, does not exhibit this behavior. 
The glide found in certain so-called monosyllabic verbs such as 'die' poses a problem. Phonetically, the quality of the (front) glide is different from that found elsewhere in the language: it has an audibly lower height, as indicated by the transcription with the symbol [ ${ }^{\mathrm{e}}$ ]. Note also that this glide-like segment does not trigger raising to mid. As far as we are aware, this segment does not occur elsewhere within words, and there does not appear to be a back counterpart to this glide.

$\begin{array}{ll}\text { (41) } \operatorname{ogok}^{\mathrm{e} a} & \text { 'to dawn' } \\ \operatorname{ogos}^{\mathrm{e}} \text { á } & \text { 'to grind' } \\ \operatorname{okoh}^{\mathrm{e} a} & \text { 'to be burnt' } \\ \text { okor }^{\mathrm{e} a} & \text { 'to eat' }\end{array}$

It would be plausible to argue that these stems contain underlying lower-mid vowels, since the applied form of these verbs exhibits a lower-mid vowel (42). Cammenga [1994] argues for a rule raising a vowel by one degree of height when it is followed by another vowel, and, assuming such a process in the language, one might propose the underlying roots $-k \varepsilon-,-s \varepsilon-$, $-h \varepsilon-$, and $-r \varepsilon-$, respectively. The infinitive forms would then derive by this prevocalic vowel raising process combined with a general diphthong-formation process.

\section{(42) ogoséćrá 'to grind for' \\ okoñérá 'to eat for'14}

Having established that palatal consonants and glides trigger Raising to High, one would predict that upper-mid vowels should not appear within a stem before one of these consonants. This prediction appears to be correct. On the other hand, palatal consonants and glides are not prohibited from appearing after a lower-mid vowel, as a comparison of (43) and (44) suggests. As noted in section 3 , the causative suffix triggers Raising to Mid-compare okogésyá 'to make harvest' with okogésa 'to harvest'-but the glide of that suffix derives underlyingly from a high vowel. Palatal consonants are transparent to Raising to Mid, which is triggered by a following high vowel (45). Note also that the underlying high vowel of the causative, which surfaces as the glide $y$, does trigger raising of lower-mid stem vowels across a palatal consonant (46).
(43)

$\begin{array}{ll}\text { ugusíña } & \text { 'to be absent' } \\ \text { ukuhíináa } & \text { 'to bend (tr.)' } \\ \text { ugutúúñá } & \text { 'to try' }\end{array}$
ugutúúyá
ukurúruuchá
uguchúúchá
'to urge'
'to buzz (of insects)'
'to filter beer'

14 The applied form of the verb 'eat' irregularly changes its initial consonant to $\tilde{n}$. 


\begin{tabular}{|c|c|c|c|}
\hline $\begin{array}{l}\text { 4) ogokéña } \\
\text { okoréćñá } \\
\text { ogotéćñá }\end{array}$ & $\begin{array}{l}\text { 'to run' } \\
\text { 'to tremble' } \\
\text { 'to collect firewood' }\end{array}$ & $\begin{array}{l}\text { umwé́ya } \\
\text { ukwé́ya } \\
\text { okogéya }\end{array}$ & $\begin{array}{l}\text { 'a gap' } \\
\text { 'to sweep' } \\
\text { 'to persuade' }\end{array}$ \\
\hline $\begin{array}{l}\text { okobócha } \\
\text { okobóx́chá } \\
\text { okohóchchá }\end{array}$ & $\begin{array}{l}\text { 'to vomit (of baby)' } \\
\text { 'to peck' } \\
\text { 'to keep from straying' }\end{array}$ & $\begin{array}{l}\text { omó́yo } \\
\text { okó́yókă } \\
\text { okohósyá }\end{array}$ & $\begin{array}{l}\text { 'heart' } \\
\text { 'to be greedy' } \\
\text { 'to play' }\end{array}$ \\
\hline $\begin{array}{l}\text { omokéñi } \\
\text { omotééñi } \\
\text { omorééñi }\end{array}$ & $\begin{array}{l}\text { 'runner' } \\
\text { 'firewood collecter' } \\
\text { 'trembler' }\end{array}$ & $\begin{array}{l}\text { omogéyi } \\
\text { ukweéyi } \\
\text { omobóchi }\end{array}$ & $\begin{array}{l}\text { 'persuader' } \\
\text { 'sweeper' } \\
\text { 'vomiting baby' }\end{array}$ \\
\hline $\begin{array}{l}\text { okokéñyá } \\
\text { okorééñyá } \\
\text { ogotéényá }\end{array}$ & $\begin{array}{l}\text { 'to make run' } \\
\text { 'to make tremble' } \\
\text { 'to make collect fire- } \\
\text { wood' } \\
\text { 'to make peck' } \\
\text { 'to make keep from st }\end{array}$ & $\begin{array}{l}\text { ukweéyyá } \\
\text { okogéyyá } \\
\text { okohóóyyá }\end{array}$ & $\begin{array}{l}\text { 'to make sweep' } \\
\text { 'to make persuade' } \\
\text { 'to play' }\end{array}$ \\
\hline
\end{tabular}

Palatal consonants and glides are also transparent to Progressive Lowering, as shown by the fact that suffixes with underlying upper-mid vowels cause lowering after lower-mid vowels over palatal consonants and glides, just as they do over other consonants. It is not possible to determine unambiguously whether regressive lowering of high vowels to upper-mid vowels is blocked by glides and palatal consonants. As the data in (48) establish, that process does not appear to apply across glides and palatals.

\begin{tabular}{|c|c|c|c|}
\hline $\begin{array}{l}\text { ogokéñéră } \\
\text { ogotéćñ́rá }\end{array}$ & $\begin{array}{l}\text { 'to run for' } \\
\text { 'to collect firewood }\end{array}$ & $\begin{array}{l}\text { ukwé̃y yéră } \\
\text { okogéyéră }\end{array}$ & $\begin{array}{l}\text { 'to sweep with' } \\
\text { 'to persuade for' }\end{array}$ \\
\hline okobóว́chérá & 'to peck with' & okohóóyérá & 'to play with’' \\
\hline okohóóchéká & $\begin{array}{l}\text { 'to be kept from } \\
\text { straying' }\end{array}$ & okoóyókă & 'to be greedy' \\
\hline
\end{tabular}
(48) ugusíñéră
ukuñúñóóntera
ukumíñoongóra
uguchúúchérá
'to be absent for' < ugusíña
'to be absent'
'to be chilled for' < ukuñúñúnta 'to be chilled'15
uguchúúnchóóréra 'to crawl away for' < uguchúúnchúúra 'to crawl away'

15 The tone of this verb appears irregular in contrast to analogous forms such as ogo-káraangá 'to fry', oko-bá-maahá 'to see them'. We suspect that the fact that the stem is partially reduplicated is relevant, since reduplicated verbs have special tonal properties. 
There are two explanations for the apparent failure of Regressive Lowering here. One possibility is that glides and palatal consonants block the process directly. Or, it is possible that the effect of Regressive Lowering is simply obliterated by the independent raising of mid vowels before a glide or palatal consonants, a process that is independently motivated.

\section{Vowel Merger}

Kikuria does not freely tolerate sequences of adjacent vowels, and rather than maintaining vocalic hiatus, processes of syllable fusion take place (see Rosenthall [1994] for discussion of hiatus-resolution in a number of Bantu languages from the perspective of Optimality Theory). The resolution of vowel hiatus depends on a number of factors, such as the height of the vowels and their backness. In a sequence of two underlying mid vowels, if the two vowels differ in backness, the first vowel becomes a glide.

$$
\begin{aligned}
& \mid \mathbf{e}+\mathbf{\jmath} / \rightarrow \text { [yวo] } \\
& \text { im[yวó]ro } \\
& \text { im[yo]ŕro } \\
& \text { /eme-óro/ } \\
& \text { /eme-órro/ } \\
& \text { im[yงว́]ys } \\
& \text { /eme-óys/ } \\
& \text { 'rivers' } \\
& \text { 'fires' } \\
& \text { 'hearts' } \\
& \mid \text { e+o/ } \rightarrow \text { [yoo] } \\
& \text { im[yoó]ño } \\
& \text { /eme-óño/ } \\
& \text { 'salts' } \\
& \text { mbar[yoo]roóra } \\
& \text { /mbare-oroóra/ } \\
& \text { 'they will float (rem.)' } \\
& \text { mbar[yoo]maná /mbare-omaná/ } \\
& \text { 'they will quarrel (rem.)' } \\
& \text { (cf. mbaretereká } \\
& \text { 'they will brew (rem)') } \\
& \text { lo+e/ } \rightarrow \text { [wee] } \\
& \text { uk[weé]ba } \\
& \text { /oko-éba/ } \\
& \text { uk[weé]ga } \\
& \text { /oko-éga/ } \\
& \text { 'to forget' } \\
& \text { [wee]b̌̌ } \\
& \text { /o-ebě/ } \\
& \text { um[weé]ng'e } \\
& \text { /omo-éng'e/ } \\
& \text { 'to learn' } \\
& \mid \mathbf{o}+\boldsymbol{\varepsilon} / \rightarrow \text { [we }]
\end{aligned}
$$

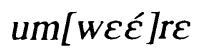

$$
\begin{aligned}
& \text { /omo-źrع/ } \\
& \text { /oko-Égékă/ }
\end{aligned}
$$

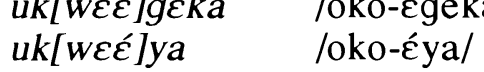

$$
\begin{aligned}
& \text { 'may you forget!' } \\
& \text { 'short (cl. 1)' }
\end{aligned}
$$

Glide Formation also takes place when $e$ is followed by e or $\varepsilon(50)$. However, if the two vowels are $o+o$ or $o+\jmath$, they fuse into a single long vowel with the quality of the second vowel (51). 
(50) $/ \mathbf{e}+\mathrm{e} / \rightarrow$ [yee]

\begin{tabular}{|c|c|c|}
\hline $\begin{array}{l}\text { mba[ryee]bă } \\
\text { im[yeé]ri } \\
\text { im[yeé]ng'e }\end{array}$ & $\begin{array}{l}\text { /m-ba-re-ebă/ } \\
\text { /eme-éril or /eme-éril } \\
\text { /eme-éng'e/ }\end{array}$ & $\begin{array}{l}\text { 'they will forget (rem.)' } \\
\text { 'months' } \\
\text { 'short (cl. 4)' }\end{array}$ \\
\hline $\mid \mathbf{e}+\boldsymbol{\varepsilon} /$ & & \\
\hline 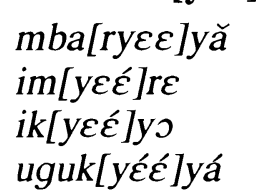 & 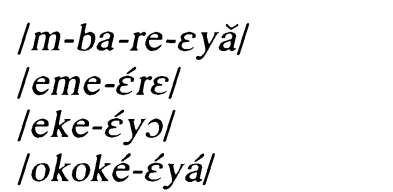 & $\begin{array}{l}\text { 'they will sweep (rem.)' } \\
\text { 'bamboo stalks' } \\
\text { 'broom' } \\
\text { 'to sweep it (Cl. 7)' }\end{array}$ \\
\hline
\end{tabular}

(51) $/$ oo/ $\rightarrow[$ oo $]$

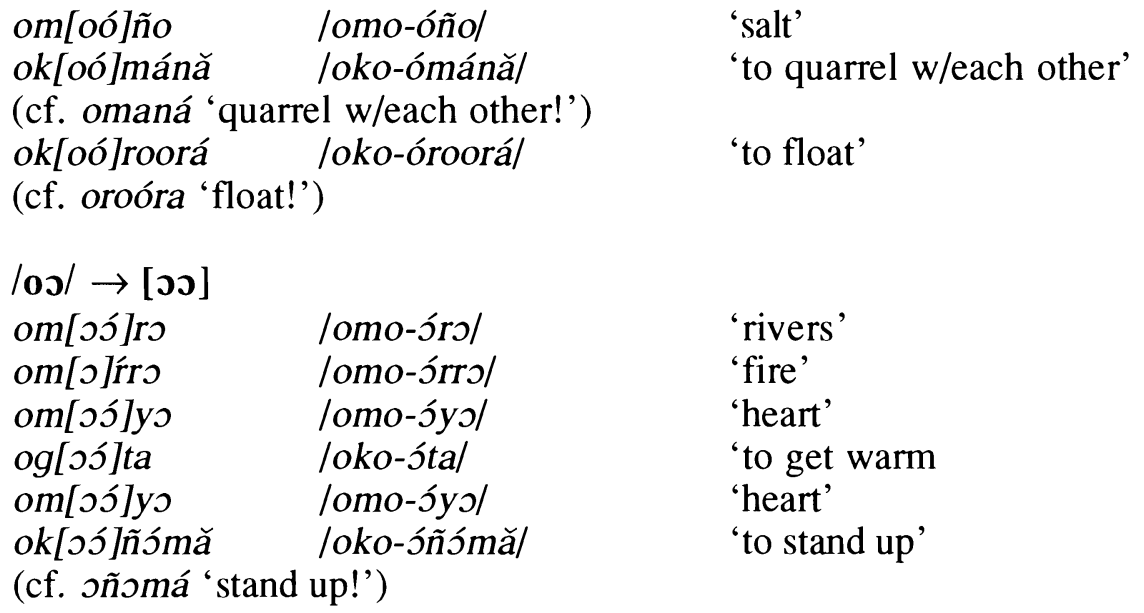

Parallel to the treatment of $/ \mathrm{e}+\mathrm{e} /$ and $/ \mathrm{e}+\varepsilon /$, one would have expected * [woo] and $*[w 00]$. The resulting sequence of like vowels and glides is apparently too similar, and leads to dissimilation in the form of deletion of $w$ before a round vowel (see Odden \& Odden [in press] for discussion of analogous phenomena in Kihehe).

A further complication shows that this expectation is not entirely incorrect, since in cases in which the underlying vowel sequence is word initial, and where no consonant precedes to form a syllable onset, then /o+ $\partial /$ becomes [wos] but $/ 0+o /$ becomes [oo], as in (52).
(52) oomě
|o+oměl
ooroóre
/o+oroóre/
'that you quarrel'
woวñok
|o+oñoké|
(cf. oksóñókă
/oko-óñókăl
'that you float'
'that you stand up'
'to stand up') 
Syllables in Kikuria generally, though not universally, have an onset consonant that can be provided through syllable fusion. When a vowel sequence appears in word initial position, no other consonant can be recruited to serve as the syllable onset. In that case, the first of the underlying vowels becomes a glide, to provide the syllable with an onset. Notice though that this happens only when the second of the vowels is [o]; that is, the segmental sequence [wo] is dispreferred (since it is avoided in [okośñomă]) but tolerated in case no other segment can provide a syllable onset, whereas the sequence [wo] is simply not tolerated at all, even for the sake of providing a syllable onset.

If the second vowel is /a/ (53), a preceding non-high vowel undergoes Vowel Merger with that /a/, so that /oa/ surfaces as [oo] and /ea/ surfaces as [ $[\varepsilon \varepsilon]$.

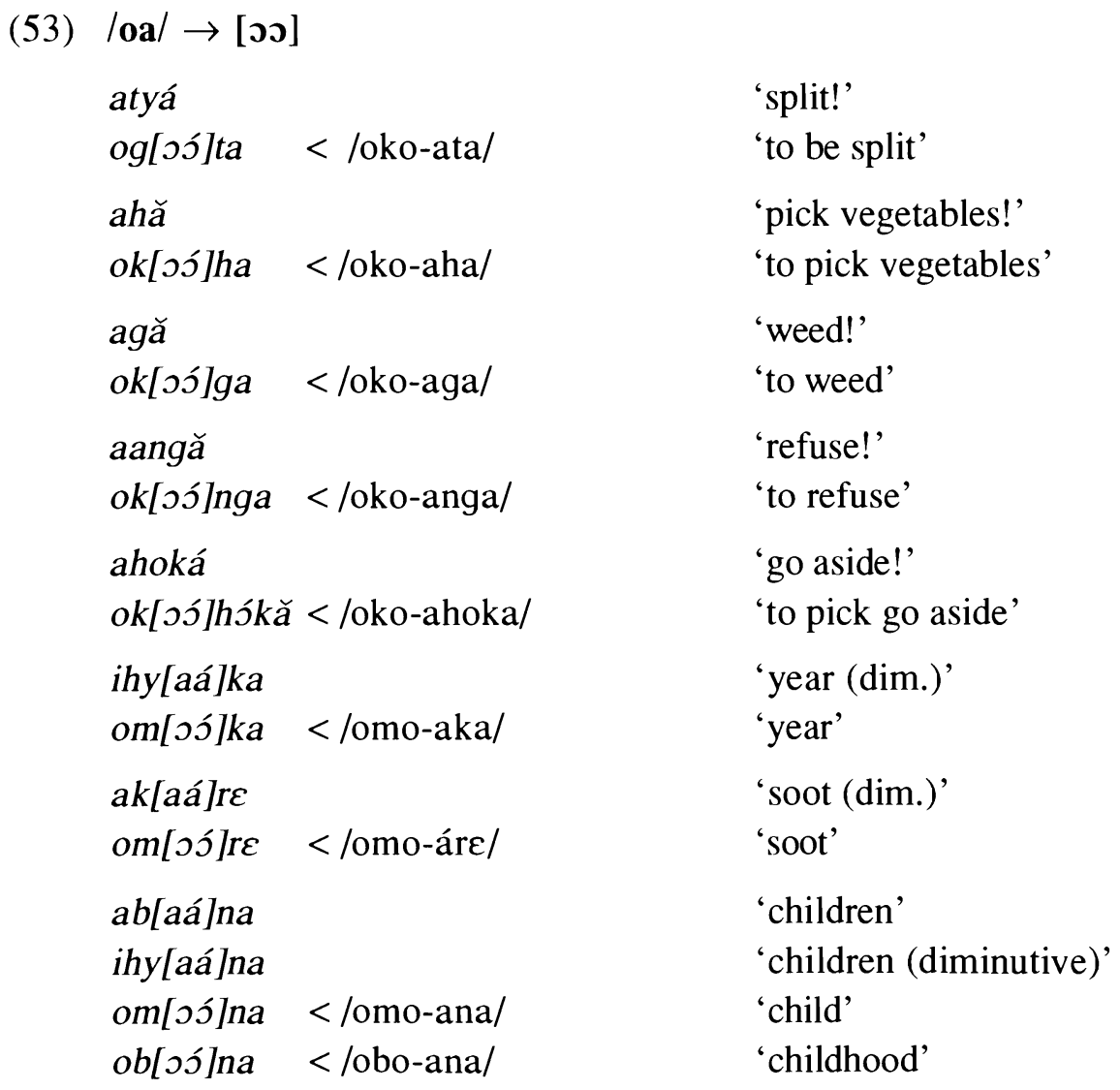




\begin{tabular}{|c|c|c|}
\hline 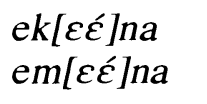 & $\begin{array}{l}</ \text { eke-ana/ } \\
</ \text { eme-ana/ }\end{array}$ & $\begin{array}{l}\text { 'child (diminutive)' } \\
\text { 'children (augmentative)' }\end{array}$ \\
\hline 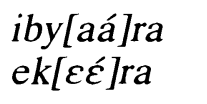 & $</$ eke-ara/ & $\begin{array}{l}\text { 'fingers' } \\
\text { 'finger' }\end{array}$ \\
\hline 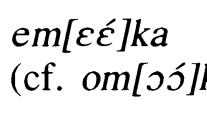 & $\begin{array}{l}</ \text { eme-aka/ } \\
\text { ka, ihy[aá]ka }\end{array}$ & $\begin{array}{l}\text { 'years' } \\
\text { ‘year', 'year (dim.)’) }\end{array}$ \\
\hline 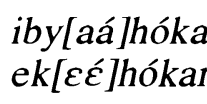 & $\begin{array}{l}\text { anyó } \\
\text { nyó </eke-áhókanyó/ }\end{array}$ & $\begin{array}{l}\text { 'differences' } \\
\text { 'difference'16 }\end{array}$ \\
\hline $\begin{array}{l}\text { [aa]ndeká } \\
\text { mbar[ع́́]nd }\end{array}$ & </mbare-ándéka/ & $\begin{array}{l}\text { 'write!' } \\
\text { 'they will write (rem.)' }\end{array}$ \\
\hline
\end{tabular}

As was the case with Glide Formation, Vowel Merger is not found, and instead one finds Glide Formation, just in case the vowel sequence is wordinitial (54). Glide Formation, rather than Vowel Merger, is found since the latter process provides the syllable with an onset consonant.

(54) waandeké $\quad</$-andeké/
waaȟ̌ 'that you write'

'that you pick vegetables'

Vowel Merger fails to apply in certain words, and instead Glide Formation applies. In these examples (55), the explanation for exceptional failure of Vowel Merger lies in the fact that the words are contemporary loan words borrowed from Swahili: chalo, chama, and mwalimu. Application of Vowel Merger would result in forms which are apparently viewed as phonologically too different from the Swahili source.

(55) ikyaáro

ugwaáro

ikyaáma

umwaárímu
$<$ leke-áro/

$<$ logo-árol

$<$ leke-ámal

$<$ lomo-árímul 'country'

'huge country'

'political party'

'teacher'

In the mirror image of this vowel sequence, Vowel Merger also fuses /ao/

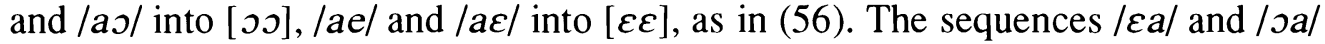
do not arise.

16 In the example ekećhókanyó, the following vowel is mid-high $o$, not $\Omega$ as would be expected by Progressive Lowering. The raising of $\supset$ to $o$ in the syllable ho is conditioned by the following causative suffix, $-y-$. 
(56) $/ \mathbf{a s} / \rightarrow[\mathbf{o s}]$

\begin{tabular}{|c|c|c|}
\hline $\begin{array}{l}\text { ak[oś]ro } \\
\text { ak[ọ́́]yo }\end{array}$ & $\begin{array}{l}</ a k a-o r \jmath / \\
</ a k a-\delta y \jmath /\end{array}$ & $\begin{array}{l}\text { 'river (diminutive)' } \\
\text { 'heart (dim)' }\end{array}$ \\
\hline \multicolumn{3}{|l|}{$/ \mathbf{a o} / \rightarrow[\mathbf{0}]$} \\
\hline $\begin{array}{l}\text { bak[oo]mană } \\
\text { bak[oo]roorá }\end{array}$ & $\begin{array}{l}<\text { /baka-omană/ } \\
<\text { /baka-oroorál }\end{array}$ & $\begin{array}{l}\text { 'and then they quarrelled' } \\
\text { 'and they will float' }\end{array}$ \\
\hline \multicolumn{3}{|l|}{$/ \mathbf{a} \varepsilon / \rightarrow[\varepsilon \varepsilon]$} \\
\hline 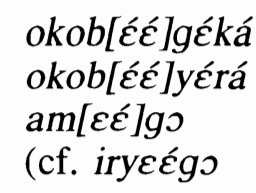 & 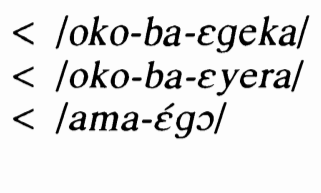 & $\begin{array}{l}\text { 'prop up against them' } \\
\text { 'to sweep for them' } \\
\text { 'teeth' } \\
\text { 'tooth') }\end{array}$ \\
\hline \multicolumn{3}{|l|}{$/ \mathbf{a e} / \rightarrow[\varepsilon \varepsilon]$} \\
\hline 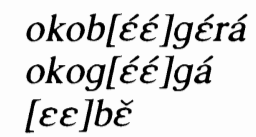 & $\begin{array}{l}<\mid \text { loko-ba-egeral } \\
<\mid \text { loko-ga-egal } \\
<|a-e b \check{\varepsilon}|\end{array}$ & $\begin{array}{l}\text { 'to learn for them' } \\
\text { 'to learn them }(\mathrm{Cl} 6) \\
\text { 'may he forget!' }\end{array}$ \\
\hline
\end{tabular}

\section{Interaction of processes}

The final issue to be considered is how these processes interact with each other. Such interaction is non-trivial, given the conflicting patterns of raising and vowel lowering exhibited in the language. Certain interactions between processes are surface transparent. Thus, raising of upper-mid vowels to high vowels, as in (57), can override the potential lowering effect of high vowel lowering, since underlying $\mathrm{CiCeCi}$ surfaces as $\mathrm{CiCiC} i$. One might expect $\mathrm{C} i \mathrm{C} e$ to become $\mathrm{CeC} e$ by Regressive Lowering: however, one equally expects $\mathrm{Ce} e \mathrm{C} i$ to become $\mathrm{CiCiCi}$ by Raising to High.

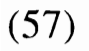

$\begin{array}{ll}\text { ugusíkíryá } & \text { /oko-siik-er-i-a/ } \\ \text { ukurúgíryă } & \text { /oko-rug-er-i-a/ } \\ \text { ugusúkíryă } & \text { /oko-suk-er-ia/ } \\ \text { ukuríngíryá } & \text { /oko-riing-er-i-a } \\ \text { ugusínd'iryá } & \text { /oko-siind-er-i-al }\end{array}$

'to make close for'

'to make cook for'

'to make plait for'

'to make fold for'

'to make win for'

A non-trivial interaction is found between the two raising processes, as illustrated in forms such as okorógyá 'to make bewitch' from /oko-rog-i-a/. Raising to Mid has applied in the surface form, but it is important to note that the surface form is identical in terms of vowel quality to the underlying form of ukurúgyá 'to make cook' (cf. okoróga 'to cook'), which has undergone Raising to High. Stated in rule-ordering terms, Raising to Mid counterfeeds Raising to High, since the output of the former process could, in principle, undergo the 
latter process, but does not. This interaction can also be explained in purely structural terms under the model of vowel height proposed by Parkinson [1996], to which the reader is referred.

Another interesting interaction is the one between Progressive Lowering and Raising to High, and a relevant underlying structure would be something like $\mathrm{C} 2 \mathrm{C} e \mathrm{C} i$. On the one hand, Progressive Lowering would lower stem-medial e to $\varepsilon$ after the vowel $\rho$, but on the other hand, Raising to High could raise that same e to $i$. In fact, there are two possible surface results in such structures, as shown by the examples in (58).

(58) a. okogéséryă okogésíryă

'to make harvest for'

ogoséénséryá ogoséénsíryá

'to make winnow for'

ogotérékeryá ogotérékiryá

'to make brew for'

b. okorógéryă okorógíryă

'to make bewitch for'

ogosókéryă ogosókíryă

'to make poke for'

okogóógéryá okogóógíryá

'to make slaughter for'

okogóótéryá okogóótíryá

'to make hold for'
< okogésa 'to harvest'

< ogoséćnsá 'to winnow'

< ogotérékă 'to brew'

< okoróga 'to bewitch'

< ogosóka 'to poke'

< okogóógá 'to slaughter'

< okogóótá 'to hold'

These two variants can be explained in terms of different interactions between the raising and lowering processes. We begin with the first variant in each set, as exemplified by okorógéryă 'to make bewitch for'. The underlying form is /oko-rog-er-i-a/. Accounting for the form okorógéryă seems problematic, since surface $e \mathrm{C} y a$ should only arise from underlying $\varepsilon \mathrm{C} y a$. Although that vocalic sequence is not found in the underlying form, it would arise in a derivational account of these processes, by applying Progressive Lowering to the underlying form, resulting in okorsgeria. Subsequent application of Raising to Mid would then raise both lower-mid vowels before the causative suffix in the usual manner, giving the surface form. The variant okorógíryă can be derived by first applying Raising to High to the underlying form, giving okorógíryă, which then undergoes Raising to Mid, giving okorógíryă. The crucial factor involved in accounting for these two variants is how Raising to High interacts with Progressive Lowering - if Raising to High takes precedence over lowering, 
then lowering is deprived of the opportunity to apply and mid vowels, not high vowels, appear on the surface.

Another interaction, between Vowel Merger and Progressive Lowering, can be observed in (59). As the data show, the vowel $\supset$ derived by Vowel Merger conditions Progressive Lowering within the stem. A lower-mid vowel which is created by Vowel Merger will undergo Raising to Mid just as an underlying lower-mid vowel will (60). A derived lower-mid vowel also behaves just as an underlying lower-mid vowel does in terms of the interaction between Progressive Lowering and Raising to High. This can be seen in the causative forms in (61).

(59)

okगóndékă
ogośtékă
okगógéră

(60) okoógyá
ogoótyá

(61) okoóndékyă okoógéryă ogoótéryă

'to write'
'to be broken a
'to weed for'
'to make weed'
'to split (tr.)'

'to cause to write'

'to cause to weed for'

'to split for'

$\begin{array}{ll}\text { aandeká } & \text { 'write!' } \\ \text { ată } & \text { 'be split!' } \\ \text { agă } & \text { 'weed!' }\end{array}$

oksóga

ogsóta 'to weed'

'to split (intr.)'

We have noted that there are two attested interactions between Progressive Lowering and Raising to High in cases such as $\varepsilon \mathrm{Ce} i$ when $\varepsilon$ is present underlyingly. Correspondingly, there are two possible interactions in the case of lower-mid vowels which derive by Vowel Merger. In addition to the pronunciations found in (61), the following are allowed.
(62)
okoóndíkyă
'to cause to write'
okoógíryă
ogoótíryă
'to cause to weed for'
'to split for'

Within the nominal paradigm, a similar interaction between vowel merger and raising explains the alternation seen in umuúri 'foundation measurer' from /omo-ori/ and the plural aboóri from /aba-ori/. In umuúri, vowel merger applied to $/ o+o /$ would result in an upper-mid vowel since the two underlying components of the vowel are upper-mid. Thus Raising to High gives a high vowel. On the other hand, in the case of /aba-ori/, the sequence /ao/ merges to os, which would result in *abosri, but this also undergoes Raising to Mid, yielding the surface form aboóri.

Analogous examples can be found in the operation of Vowel Merger in stems with a non-high final vowel. The stem 'rich' is underlying -áme; cf. ihyaáme 'rich (dim.)', abaáme 'rich (cl. 2)'. When the cl. 1 prefix omo- appears before 
this stem, one finds omoóme. Considering only the effect of Vowel Merger, one would expect *omośme-but Raising to Mid, triggered by the final upper-mid vowel $e$, has the consequence that the fused vowel sequence surfaces as an upper-mid vowel.

\section{Conclusion}

In this paper, we have illustrated a wide range of phonological processes relating to vocalic height in Kikuria. While height-based vowel harmony is common in Bantu languages, one generally finds a single transparent process of complete height-agreement. Because of the wealth of height-relevant processes found in Kikuria, their interaction, and their sensitivity to consonants, data from Kikuria will surely be of significance in the theoretical treatment of vowel height.

\section{REFERENCES}

Cammenga, Jillert. 1994. "Kuria phonology and morphology." Doctoral dissertation, Vrije Universiteit Amsterdam.

Clements, G. N. 1991. "Vowel height assimilation in Bantu languages." Proceedings of the Berkeley Linguistic Society17: 25-63.

Downing, Laura. 1998. "On the prosodic misalignment of onsetless syllables." Natural Language and Linguistic Theory 16: 1-52.

Hyman, Larry. 1988. "Underspecification and vowel height transfer in Esimbi." Phonology 5: 255-273.

McCarthy, John and Alan Prince. 1993. "Prosodic morphology I; constraint interaction and satisfaction." MS, University of Massachussets, Amherst and Rutgers University.

Odden, David. 1987. "Predicting tone in Kikuria." In David Odden (ed.), Current Approaches to African Linguistics 4, pp. 311-326. Dordrecht: Foris.

Odden, David and Mary Odden. In press. "Kihehe syllable structure." In Harry van der Hulst and Nancy Ritter (eds.), The Syllable: Facts and Views. Berlin: Mouton de Gruyter. 
Parkinson, Frederick. 1996. "The phonological representation of vowel height, its phonetic correlates and roles in constraint-based phonology." Ph.D. dissertation, The Ohio State University.

Rosenthall, Sam. 1994. "Vowel/glide alternation in a theory of constraint interaction." Ph.D. dissertation, University of Massachussetts, Amherst.

Department of Linguistics 222 Oxley Hall

The Ohio State University Columbus, $\mathrm{OH} 43210$

odden@ling.ohio-state.edu
[Received March 1998; revision received June 1998; accepted August 1998] 